\title{
TAX COMPROMISES AND THE STATUTE OF LIMITATIONS
}

On March 12, 1954 the Commissioner of Internal Revenue assessed deficiencies, totalling $\$ 22,306.86,{ }^{1}$ against Joseph Saladoff for the taxable years 1948, 1949, and $19500^{2}$ That November, Saladoff made the government an offer to compromise the liability for $\$ 15,000$ half to be paid within a year of acceptance of the offer, the balance in monthly installments of $\$ 300$. Shortly thereafter, he offered in addition to pay a stated fraction of his annual income until 1964, beyond the amounts set forth in the offer in compromise. ${ }^{3}$ On April 18, 1956, the government accepted his offer.

Saladoff soon fell behind in his payments, and by his death in 1961 had paid only $\$ 7,968.64$. Four months after he died, the government exercised its option, in case of breach of the payment provisions, to terminate the agreement, ${ }^{4}$ and brought suit for the full amount originally claimed, less the money already paid. Summary judgment was granted the government by a sorrowful ${ }^{5}$ district court, and the court of appeals affirmed over a claim that the bulk of the initial assessment had been barred by the statute of limitations, and thus was not appropriate for compromise. $^{6}$

1 The deficiency assessed for 1948 was $\$ 11,108.06$; for $1949, \$ 8,078.70$; and for $1950, \$ 3,120.10$.

2 United States v. Saladoff, 233 F. Supp. 255 (E.D. Pa. 1964), aff'd sub nom. United States v. Feinberg, 372 F.2d 352 (3d Cir. 1964), aff'd on rehearing en bant, 372 F.2d 359 (3d Cir. 1967). The statement of facts as here given is combined from the opinions of the district court and of the original Third Circuit panel. The figures given in the latter opinion, 372 F.2d 352, 353-55, are inconsistent and apparently in error.

3 This is common practice. Before accepting an offer in compromise, the government will frequently require that the taxpayer commit himself to pay some fraction (usually on a sliding scale) of his future income in case it is greater than estimated by the parties. See Horne, Offers in Compromise, N.Y.U. 16th Inst. on Fed. TAX. $503,510-11$ (1958).

4 The option to terminate is contained on the standard form $656-\mathrm{C}$, which must be used for offers where the full amount of the offer is not to be paid at once. See Tannenbaum, Compromises Based on Inability to Pay, N.Y.U. 10TH INST. ON FED. TAx. 838-40 (1952). The form appears at id. 860 .

5 If I were an administrator, from the facts now of record I would without hesitation recommend that the government accept a settlement in an amount considerably less than the maximum obtainable under the default provision. However, my judicial role prevents the exercise of an administrative judgment which should properly balance fairness with the undisputed power of one's legal position. It is with reluctance, therefore, that I must grant the government's motion for summary judgment and deny the taxpayer's motion for summary judgment.

233 F. Supp. at 259-60 (footnote omitted).

6 The statute of limitations defense was not raised until the motion for rehearing, at which time the taxpayer requested leave to amend the pleadings. The timeliness of this defense presented a major issue on rehearing. The court said:

It is plain that there was no intention, prior to the adverse decision of this court, to raise the three year statutory bar to the assessment of taxes for 1948 and 1949 and appellant's suggestion that now the pleadings should be permitted 
This result seems at variance with the statutory scheme. Although in tax cases arising under early revenue acts, waiver of the statute of limitations after it had run was uniformly allowed, ${ }^{7}$ Congress in 1929 modified the limitation provision, expressly making waiver of the period of limitations after it had run impossible. ${ }^{8}$ Section 6501(c)(4) of the Internal Revenue Code now allows for extension of the period only if agreed to "before the expiration of the time prescribed in this section for assessment . . . " 9 So clear is the proposition that waiver must be timely to be effective that, apparently, only one case has ever even raised the issue. ${ }^{10}$ Similarly, if collection of a liability would be barred by the statute of limitations, any subsequent payment against that

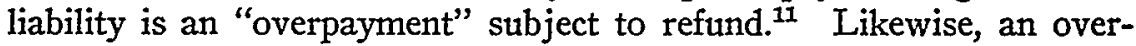
payment of another liability cannot be applied against a liability barred by the statute. ${ }^{12}$ If, therefore, Saladoff had paid the taxes assessed before executing the compromise agreement, he could have recovered the amounts claimed for 1948 and 1949 -some $\$ 19,000$-as an overpayment. And, absent the agreement, it seems clear that the statute would have been a bar to any attempt at collection by the government. ${ }^{13}$ The only question remaining is whether the agreement compels a different result.

Compromise agreements are authorized by section 7122 of the Code, which provides:

(a) Authorization.-The Secretary or his delegate may compromise any civil or criminal case arising under the internal revenue laws prior to a reference to the Department of Justice for prosecution or defense; and the Attorney General or his delegate may compromise any such case after reference to the Department of Justice for prosecution or defense.

to be so amended falls of its own weight. Such an approach is not helpful for the laze governing the existent offer in compromise is disposite of the case adversely to the appellant.

372 F.2d at 360 (emphasis added) (footnote omitted). Thus, it could be argued that so much of the opinion as deals with the substantive issue is nothing but dicta. The italicized passage, however, seems to indicate that the court would have allowed the amendment had it concluded that the taxpayer would prevail under the amended pleadings.

7 E.g., Helvering v. Newport Co., 291 U.S. 485 (1934); Stange v. United States, 282 U.S. 270 (1931).

8 Revenue Act of 1928 , ch. $852, \S 506$ (a), 45 Stat. 870 ; see S. Rep. No. 960, 70th Cong., 1st Sess. 31 (1928), reprinted in 1939-1 CuM. Bulz. (pt. 2) 409, 430.

9 Similar provisions protect the government in case refund is made after the period of limitations. INT. REv. CODE OF 1954, \$\$ 6514(a), 7405.

10 Elmer M. Melahn, 9 T.C. 769 (1947). Interestingly enough, in that case it was the taxpayer who was earnestly arguing the validity of his untimely waiver.

11 INT. REv. CODE OF 1954, §6401(a).

12 Id. $\S 6514(\mathrm{~b})$. This is true even if the payment was made before running of the statute, so long as the overpayment was not allowed until after the statute had run. McEachern v. Rose, 302 U.S. 56 (1937).

${ }^{13}$ As far as can be discerned from the opinions in the case, the government made no claim that the applicability of the statute of limitations was one of the issues compromised. Of course, if that was one of the compromised issues, there would be no reason to open the agreement. 
According to the regulations, compromises are to be entered into only if there is doubt either as to liability or collectibility. ${ }^{14}$ The justification for such compromises is of course similar to that for compromise in any civil claim. ${ }^{15}$ When liability is in dispute, both parties save the expenses of litigation in return for concessions on an uncertain future. When nothing is in question but collectibility, the section on its face seems something more of a boon to the taxpayer, although cases where the Commissioner thinks that the liability is certain may not appear equally clear to the taxpayer. But friends or relatives with assets otherwise out of the government's reach may be willing to contribute if the taxpayer may thereby wipe clean the slate. Moreover, the expenses of litigation may further deplete the taxpayer's already insufficient resources and allow the government to collect even less of the amount due.

The obvious pressures for finality in such situations have given rise to the so-called "binding effect" rule: a compromise will normally be conclusive upon the parties in the event of subsequent litigation of the issues. ${ }^{10}$ But as so stated, the rule is incomplete. Clearly, to allow the compromise of a disputed claim to be opened because one of the parties feels he is in a better position than before is to undermine the purpose of the agreement. When it is the compromised issue itself that has subsequently been made free from doubt, the proposition is obvious. The compromise was made with full understanding that the disputed issue could subsequently be determined one way or the other (as it would have had the parties proceeded to court); the compromise can even be viewed as an attempt to avoid such a resolution. There is no reason to modify the agreement because a possibility within the contemplation of the parties did in fact come to pass.

Other circumstances, however, will justify setting the agreement aside. ${ }^{17}$ In particular, mutual ${ }^{18}$ mistake over an underlying assump-

14 Treas. Reg. \$301.7122-1(a). Interestingly enough, although the Code provides for compromise of "any civil or criminal case," the regulations allow compromise only of "liability." Apparently, $\$ 7122$ compromises are never entered into when the taxpayer is seeking a refund. See notes 28 \& 31 infra.

15 See generally R. Paul, Federal Tax Compromises and Prospective Regulations, in Selectad Studies on Federal Taxatron 53 (2d series 1938).

16 See, e.g., Rubel Corp. v. Rasquin, 132 F.2d 640 (2d Cir. 1943) ; Ely \& Walker Dry Goods Co. v. United States, 34 F.2d 429 (8th Cir. 1929), cert. denied, 281 U.S. 755 (1931).

17 The regulations allow the matter to be reopened in case of fraud on the part of the taxpayer, Treas. Reg. $\$ 301.7122-1$ (c), and the courts have frequently stated that duress on the part of the government would justify setting aside the agreement, although "duress" in practice seems to require action little short of physical force. See, e.g., Du Puy v. United States, 35 F.2d 990, 1003-04 (Ct. Cl. 1929). In addition, the procedural requirements of the statute must be strictly followed or the agreement will be set aside. Botany Worsted Mills V. United States, 278 U.S. 282 (1929); see Uinta Livestock Corp. v. United States, 355 F.2d 761 (10th Cir. 1966).

18 The mistake can be treated as mutual for the purposes of discussion here. If mutuality failed because the taxpayer was under no misapprehension, it is hornbook law that he cannot later raise the issue. 3 A. Corbin, Contracts $\$ 611$ (rev. ed. 1960). On the other hand, if the government realized that the statute would bar assessment of the taxes, assessment and demand for payment smacks very much of dishonorable dealing, and to refuse remedy for lack of mutuality is hardly appropriate. See Staten Island Hygeia Ice \& Cold Storage Co. v. United States, 85 F.2d 68, 71-72 (2d Cir. 1936), and cases there cited; 3 A. CoRbIN, supra, $\$ \$ 608,610,618$. 
tion is ground for the modification or rescission of the agreement. The regulations themselves allow for opening in case of "mutual mistake of a material fact," ${ }^{19}$ but apparently attempt to draw a distinction in case the mistake is one of law.

Such a blanket distinction cannot be rationally supported. The real distinction is not between "fact" and "law," but rather one that turns on the meaning of "mistake." "Mistake of fact" presupposes a real world in which, at any given time, only a single set of facts obtains. Legal relationships, however, are not so fixed. What "the law" is at a given time may vary with the time at which the question is asked. In Hord v. United States, ${ }^{20}$ for example, the parties had entered into a compromise agreement assuming that the compromised taxes were collectible at the time, an assumption justified by a decision of the Fifth Circuit Court of Appeals. ${ }^{21}$ Subsequent to the making of the agreement, the decision relied upon was reversed by the Supreme Court. ${ }^{22}$ To allow modification of an agreement in such circumstances opens too broad a door. ${ }^{23}$ When the law appears settled on a given point, the "mistake" of the parties goes not to what the law then was, but rather to the likelihood of change.

But when the mistake is not how the law might subsequently change, but rather in the state of the law at the time of the agreement, mistake of law is essentially the same as mistake of fact. ${ }^{24}$ This was precisely Mr. Saladoff's situation. The law of limitations on assessment was not (so far as material) changed subsequent to the making of the agreement. The parties were simply under a misapprehension of the law at that time. Such a misapprehension should be treated in the same way as a misapprehension of fact. ${ }^{25}$

The statement of such a rule, however, does not of itself dispose of all the problems. There remains the question of remedy. To render the entire agreement null and void is a simple solution, but hardly a

19 Treas. Reg. $\S 301.7122-1$ (c), provides:

Neither the taxpayer nor the government shall, upon acceptance of an offer in compromise, be permitted to reopen the case except by reason of (1) falsification or concealment of assets by the taxpayer, or (2) mutual mistake of a material fact sufficient to cause a contract to be reformed or set aside.

2059 F.2d 125 (Ct. Cl. 1932).

21 United States v. Russell, 22 F.2d 249 (5th Cir. 1927), rev'd, 278 U.S. 184 (1929).

22 Russell v. United States, 278 U.S. 184 (1929).

23 The court in Hord refused to open the agreement. Contra, Cloister Printing Corp. v. United States, 100 F.2d 355 (2d Cir. 1938).

24 It is frequently so treated. E.g., Barnett v. Kunkle, 256 F. 644 (10th Cir. 1919), appeal dismissed, 254 U.S. 620 (1921). See also 3 A. Corbin, Contracts $\$ 620$, at 770 (rev. ed. 1960) : 'Mistake as to a person's existing legal rights is treated as mistake of fact in determining whether such remedies as reformation or rescission and restitution should be decreed." (citations omitted).

25 Alternatively, it could be argued that the taxpayer's misapprehension went to the nature of the consideration: in executing the waiver of the statute of limitations, he did not know that the statute was an absolute bar and thought that he was giving up a far less valuable item, i.e., that he was giving the government simply an extension of time rather than reviving a barred claim. See, e.g., Sherwood v. Walker, 66 Mich. 568, 33 N.W. 919 (1887). 
desirable one. For example, if no effect were given to that portion of the agreement tolling the statute of limitations where it had not already run, ${ }^{26}$ by the time a compromise involving deferred payments was litigated the statute would likely bar collection of any unpaid taxes. Rather, the solution must be to preserve insofar as possible the compromise already made, reopening only those questions necessarily modified by the altered situation.

\section{Doubt as to Liability}

The more difficult situation is probably that in which the issue compromised was the extent of liability. In practice, this is probably the rarer case. Doubtful liability may be settled without litigation in ways other than compromise agreements, ${ }^{27}$ and it would seem that section 7122 compromise agreements are never entered into when it is the taxpayer who is seeking money from the government. ${ }^{28}$ Although the extent to which liability is doubtful may appear different to the taxpayer than to the government, ${ }^{29}$ it appears that the government most often enters into such agreements when it believes that liability is clear and the only question is collectibility. ${ }^{30}$

When a compromise over liability is opened, however, the best solution would normally be to preserve the agreement to the extent feasible. If, for example, the disputed question was the amount of income received and the mistaken underlying assumption was the applicable tax rate, the compromise arrived at with respect to the amount would be clear (either explicitly or implicitly) from the agreement. In many situations it would be possible to consider the agreement reached as binding insofar as the amount of income is concerned, and simply apply the different rate schedule to that amount.

This will not dispose of the problem in all circumstances. Where the proper rate is substantially higher than the one assumed, the taxpayer can plausibly argue that he was induced to agree to a compromise on the amount of income taxable only because of the smaller amount of taxes for which he would be liable, and that to bind him to the compromised amount while increasing the rate payable on that amount is to do violence to the very thing he was seeking to compromise: in such a

28 See note 36 infra and accompanying text.

27 The normal administrative settlement is by execution of Form 870 or 870-AD. Also available are closing agreements, see INT. REV. CODE of 1954, \$ 7121; Treas. Reg. $\$ 301.7121-1$; cf. Note, The Consent Judgment as an Instrument of Compromise and Settlemerrt, 72 HARv. L. Rev. 1314 (1959).

28 See note 14 supra. No case has been found mentioning such an agreement, and at least two articles on tax compromises seem to indicate that no such compromises are entered into. Horne, Offers in Compromise, N.Y.U. 16TH INST. ON FED. TAX. 503 (1958); Tannenbaum, Compromises Based on Inability to Pay, N.Y.U. 10TH INST. oN FED. TAX. 839 (1952).

29 As in the case under discussion. United States v. Saladoff, 233 F. Supp. 255, 259 (E.D. Pa. 1964).

30 Horne, supra note 28 , at 503 . 
situation his interest is not in issues of law, but simply in the amount of money that he will have to pay. ${ }^{31}$ In such situations, the only logical approach would be to open the compromised question for further litigation or compromise.

\section{Doubt as to Collectibility}

In the second type of compromise, the equities might appear not to be as evenly balanced. The government seems to be giving the taxpayer a reduction in liability in return solely for a waiver of nuisancevalue rights: by hypothesis, if liability is clear the taxpayer is simply being obstreperous by forcing the government to bring suit to collect its money. The hypothesis, however, is open to doubt on two points. First, liability that seems clear to the government may not seem equally clear to the taxpayer. Second, offers in compromise often give the government benefits not available through suit. Payments are frequently deferred, and the government in this way may be able to collect substantially more money than would be available by a judgment and forced sale of the taxpayer's assets. ${ }^{32}$ The taxpayer is encouraged to work off his debt by reduction of his liability, an option not available if the case is brought to court. Likewise, friends and relatives may contribute assets not subject to levy in order to give the taxpayer a fresh, unencumbered start.

Compromises based on collectibility should still not be given the same treatment as compromises of liability. If the underlying mistake reduces the taxpayer's liability by half, there is no reason to similarly reduce the amount due under the agreement: the issue compromised was not how much the taxpayer should pay, but how much he could pay. So long as liability after allowance for the mistake still exceeds the amount to be paid under the agreement, there is no reason for reduction of the latter. On the other hand, if the agreement calls for payment of more money than was actually due, the fact that the taxpayer was able to pay that amount should not mean that he is forced to do so.

31 Two factors render it less plausible for the government to make a similar argument. First, as already mentioned, the government apparently never uses $\$ 7122$ to compromise cases where the taxpayer is seeking a refund, although such cases are, of course, frequently settled. Consequently, it is never going to be forced to pay out more money than it anticipated when making the compromise. Second, if the dispute was over liability it is hard to believe that the government would have entered into an agreement not because of the degree of doubt over the liability, but rather because it felt it had gotten "enough" and that collection of more was unnecessary. Such a rationale is, essentially, one of leniency because of possible harshness of the tax law itself, a ground on which compromises are not designed to be made. See TrEAs. REG. $\S 301.7122-1(\mathrm{a})$; Horne, supra note 28 , at 505.

32 The government's assessment of its ability to collect from the taxpayer is based on the forced sale value of his assets. Tannenbaum, supra note 28 , at 846 . Collateral agreements, requiring a promise to pay a specified percentage of the taxpayer's annual income for some future period, are being required with increasing frequency. See Horne, supra note 28, at 510-11. 


\section{Resolution}

In no case are the issues likely to be completely clear, and the procedural setting of the controversy will bear strongly on its resolution. To say that an agreement may be reopened upon subsequent discovery of an underlying mistake does not mean that it may be reopened at any time. If the taxpayer has complied with the agreement and is seeking refund of the money paid, the statute of limitations ${ }^{33}$ will in many if not most cases bar his recovery of much or all of the money paid.

Two questions must be faced in every case. First, does the underlying mistake warrant opening the agreement? Second, what portions of the compromise should be modified? Mr. Saladoff's mistake clearly warrants opening the compromise. As to the second question, a retroactive waiver of the statute of limitations embodied in the compromise agreement is in no sense like a negotiated term of a private contract: if anything, it is a contract of adhesion. The waiver appears on a printed form that is evidently required for all compromise agreements; the taxpayer must accept the term or forego the compromise. ${ }^{34}$ That in itself, of course, is hardly sufficient to void the agreement. ${ }^{35}$

But the retroactive aspect of the waiver is sufficient. Of course, if the issue compromised was whether or not the period of limitations had run, a subsequent determination that it had indeed run would no more affect the agreement than a subsequent determination of any other compromised matter. In Feinberg, for example, evidence on the part of the government that there was doubt about the applicability of the statute would justify the result. ${ }^{36}$ But unless the compromise went to that issue, a retroactive waiver of the statute of limitations should lose none of its illegality for the fact of being embedded in a compromise agreement.

33 INT. Rev. Code of 1954, § 6511.

34 Form $656-\mathrm{C}$ is set out as an appendix to Tannenbaum, supra note 28 , at 860 . See also id. at 841-43.

35 The regulations as well as the form contract require the taxpayer to waive the running of any limitations on limitation or collection. Treas. Reg. \$301.7122-1(f) provides:

No offer in compromise shall be accepted unless the taxpayer waives the running of the statutory period of limitations on both or either assessment or collection of the tax liability involved for the period during which the offer is pending, or the period during which any installment remains unpaid, and for one year thereafter.

Such a requirement, of course, legitimately protects the government, which typically does not resort to the more drastic measures available to it while considering an offer in compromise. And this requirement by no means conflicts with the statutory scheme: INT. REv. CoDE of 1954, §6501(c) (4) expressly provides for just such extensions of the limitations.

36 INT. REv. CoDE of 1954, $\$ 7122$ (b), requires the Treasury Department to place on record its reasons for compromise of any liability where the amount of unpaid tax is greater than $\$ 500$. 